\title{
Um mundo diferente. Que mundo é este que, para mim, é diferente?
}

É um mundo diferente daquele escolhido pela maioria dos profissionais liberais, sejam médicos, advogados, engenheiros (e outros) que não se inclinam ao caminho traçado pela vida acadêmica.

Se para todos, o estudo contínuo, ininterrupto em suas respectivas áreas, é necessário, para aqueles que abraçam a vida acadêmica, com dedicação ao estudo avançado, às novas experiências e às pesquisas, é ainda mais imprescindível, já que a propagação desses conhecimentos à nova geração é a meta maior, que norteia toda a atividade.

A vida acadêmica proporciona, a nós que a ela nos dedicamos, uma satisfação muito grande, uma alegria enorme em poder dividir com os pós-graduandos e com o jovem acadêmico da iniciação científica, a experiência acumulada em anos e anos de trabalho, pesquisa e estudo. Ficamos felizes em poder abrir caminhos, mostrar novas perspectivas, estimular o pensamento criativo, que talvez um dia possa alcançar descobertas interessantes.

Para isso, entretanto, há que estar preparado para ser um orientador competente, não apenas na parte científica, embasado no conhecimento profundo da matéria, mas também ter um espírito aberto às indagações do aluno, seus interesses e seus anseios. Sempre pronto a esclarecer: a divergir quando necessário, a apoiar e enaltecer quando merecido. A vitória deles é a nossa vitória maior e é também a nossa realização como mestre.

Grato pelo convite.

Fernando Oréfice Professor Titular de Oftalmologia da Universidade Federal de Minas Gerais 